\section{Influence of Reproductive Impairment of Most Developed Flowers on Fruit Set and Fruit Quality in Pear}

\author{
Carlos Miranda, ${ }^{1}$ Luis G. Santesteban, and José B. Royo \\ Departamento de Producción Agraria, Sección de Fruticultura y Viticultura, \\ Universidad Pública de Navarra, Campus de Arrosadia, 31006 Pamplona, Spain
}

Additional index words. Pyrus communis, thinning, parthenocarpy, fruit set, fruit weight

\begin{abstract}
The lowest flower in the pear (Pyrus communis L.) cluster usually develops and blooms first and also has a greater sink potential. For this reason, resources are preferentially utilized by the lowest fruit, and this is also one of the reasons why most thinning practices tend to favor their set. However, it is not always possible to perform selective thinning. This study was undertaken to determine if hindering pollination in the most developed flowers in the cluster influences yield or quality compared to that obtained in a whole open-pollinated cluster. The treatments were made in 'Blanquilla' (Spadona, Agua de Aranjuez) and 'Conference' pear within a wide range of flower densities for each cultivar. Pollination was hindered by cutting off the flower styles. The factor tested was style removal intensity (SRI). Treatments consisted in removing the styles of two, four(always the most developed), or all flowers in each cluster. Flower density was used as a covariate in an analysis of covariance to account for differences in flower densities in response to SRI treatments. In all experiments the covariate was not significant; therefore, SRI effect was not affected by flower density. 'Blanquilla' and 'Conference' had similar responses to treatments, so that when at least three flowers are susceptible to be openly pollinated, fruit set, seed content, and cluster yield were similar to control clusters, therefore the growth potential of fruit from partially damaged clusters in their most developed flowers is similar to undamaged open pollinated clusters. The reduced set of parthenocarpic clusters implies yield reductions ranging between $40 \%$ and $60 \%$ in 'Conference', and up to about $60 \%$ in 'Blanquilla'.
\end{abstract}

In most pear (Pyrus communis L.) cultivars, the blooming sequence of flowers within the cluster is centripetal, i.e., the lowest flower starts to bloom first and the other flowers open succesively upwards (Dibuz, 1997). The most developed flower has a greater number of cells and better vascular development (Westwood et al., 1967), as well as a greater sink potential, and, in pear, it is generally assumed that, as in apple, resources are preferentially used by these flowers, which reduces the set and size of the nearest fruit (Black et al., 2000; Ferree et al., 2000; Goffinet et al., 1996). However, although it is well known that apple flower dominance is not the same for all cultivars (Dennis, 1986, 2003; Ferree et al., 2000), there is no similar information available for pear. Natural selfregulation in pear has been generally considered to be sufficient from a horticultural perspective. However, as production and international trade are increasing and customers are demanding a better fruit quality, prices for small and mediumsized fruit remain constant or are declining (Dennis, 2000). As a consequence, a reduction in the number of fruit per tree by thinning is desirable and, the earlier the thinning takes place, the more beneficial is its effect, either for a good bloom return of for an adequate fruit

Received for publication 4 Feb. 2005. Accepted for publication 1 Mar. 2005. This study was financed by Agroseguro S.A.,Agrupación Española de Entidades Aseguradoras de los Seguros Agrarios Combinados S.A. C/Gobelas 23, 28023 Madrid, España.

${ }^{1}$ To whom reprint request should be addressed; e-mail carlos.miranda@unavarra.es. development (Wertheim, 2000). Most blossom thinning practices tend to take advantage of the greater potential in the size of the most developed flowers, and favor their set when possible. This is one of the reasons why the application of caustic blossom thinners is recommended at the stage when, in most clusters, only the most developed flower is open and pollenized, i.e., at first bloom (Fallahi and Willemsen, 2002; Wertheim, 2000).At this stage, the upperflowers are still at the popcorn stage, or slightly (but not completely) open and hopefully not fertilized, so that these caustic thinners damage different flower parts, including anthers, stigmas, styles or pollen tubes (Bound and Jones, 1997; Byers and Lyons, 1985; Fallahi and Willemsen, 2002), preventing their fertilization. The flowers already fertilized are unaffected and can continue their development.

However, selective thinning is not always a straightforward process and its practice is facing many drawbacks. For instance the efficiency of caustic thinners strongly relies on the fact that a particular flower is hit by enough droplets. On the other hand, mechanical thinning machines, such as those proposed for thinning the fruit wall training system (Masseron, 2002), often damage or cut only the bigger and most developed flowers. Finally, spring frosts of moderate intensity will only kill the most developed flowers in the cluster, because flower development is associated with a progressive increase in its vulnerability to low temperatures (Baldini, 1992; Westwood, 1993). Few studies, always performed in apple, have included the removal of the most developed flowers in their treatments when comparing set or growth ability of the different flower positions within the cluster. When apple clusters were hand-thinned leaving a single fruit of known position within the cluster, there were no statistical differences among flower positions in fruit weight, fruit size or seed count at harvest (Ferree et al., 2001; Goffinet et al., 1996), concluding that early thinning allows the most mature lateral flowers to achieve an equal size to that of the king flowers. A recent study which compared the set and yield of whole apple clusters with that obtained for thinned clusters in which only the king flower had been removed, or in which more than two lateral flowers were left alone in the cluster (Miranda et al., 2005), found that the growth potential of fruit from the first and second lateral flowers was similar to clusters with the king flower. The authors are unaware of any similar research conducted in pear cultivars, whose study implies further difficulty as a consequence of the presence of parthenocarpy. Some pear cultivars develop fruit without fertilization, but they have less set and are generally less competitive tending to shed heavily (Nyeki et al., 1994; Strang et al., 1980; Westwood, 1993), especially when seeded fruit are present in the same cluster (Goldwin, 1984). Parthenocarpic fruit are also prone to malformations and postharvest disorders (Baldini, 1992; Sanzol, 2001; Sharifani and Jackson, 2001), at least in some cultivars such as 'Blanquilla' (Spadona, Agua de Aranjuez).

The current study was undertaken to determine whether hindering the pollination of the most developed flowers in the cluster at 'first bloom' (i.e., when the lowest flower in the cluster has just bloomed) influences the yield, quality or the parthenocarpic ability of the pear fruit. 'Blanquilla' and 'Conference', which are widely grown in Spain (Prognosfruit, 2004), were evaluated in this study. 'Blanquilla', despite being one of the leading Spanish cultivars, has an erratic and often low productivity due to its short effective pollination period (Sanzol et al., 2003), low parthenocarpic strength and low self-fertility (Cambra and Herrero, 1978; Sanzol, 2001) and lack of suitable pollenizers of commercial interest (Sanzol and Herrero, 2002, 2003). 'Conference' shows the opposite productive features as it has a long effective pollination period, it is highly parthenocarpic, self-fertile, and with many suitable pollenizers (Nyeki et al., 1994, 1998, 2000).

\section{Materials and Methods}

Treatments. The research was conducted in 2001 and 2002 using two commercial orchards in full production, one per cultivar, located in Tudela (Lat. $42.04^{\circ} \mathrm{N}$, Long. $1.36^{\circ} \mathrm{W}$, altitude $264 \mathrm{~m}$ ), in the mid-Ebro river valley (Spain). The cultivars studied were 'Blanquilla' (Spadona) and 'Conference', both grafted on BA29 quince and planted in 1992. Trees were trained to oblique-palmette, and canopies reached about $2.75 \mathrm{~m}$ aboveground in height. The 'Blanquilla' orchard was isolated from other pear orchards and set up without pollenizer, which is a common practice since cropping for this cultivar often relies on the application of GA3 at bloom for the induction of parthenocarpic fruit because few 
Table 1. Mean ( \pm standard deviation), maximum ( $\max )$ and minimum $(\min )$ values for the main agronomical characteristics of the 'Blanquilla' and 'Conference' pear orchards under study. Fifteen trees were used for each treatment.

\begin{tabular}{|c|c|c|c|c|c|c|c|}
\hline \multirow[b]{2}{*}{ Cultivar } & \multirow[b]{2}{*}{$\mathrm{TT}^{\mathrm{z}}$} & \multicolumn{3}{|c|}{ Tree size $\left(\mathrm{cm}^{2} \mathrm{TCA}^{\mathrm{y}}\right)$} & \multicolumn{3}{|c|}{ No. flower buds $/ \mathrm{cm}^{2} \mathrm{TCA}$} \\
\hline & & Mean \pm SD & Min & $\operatorname{Max}$ & Mean \pm SD & Min & $\operatorname{Max}$ \\
\hline \multicolumn{8}{|c|}{ Blanquilla } \\
\hline \multirow[t]{4}{*}{2001} & NT & $126 \pm 24$ & 97 & 183 & $6.5 \pm 2.2$ & 4.7 & 11.8 \\
\hline & SR2 & $135 \pm 28$ & 95 & 187 & $6.5 \pm 2.8$ & 3.7 & 13.1 \\
\hline & SR4 & $127 \pm 25$ & 97 & 183 & $6.2 \pm 2.4$ & 3.9 & 11.8 \\
\hline & SR7 & $134 \pm 21$ & 100 & 176 & $6.3 \pm 2.6$ & 3.2 & 11.3 \\
\hline \multirow[t]{4}{*}{2002} & NT & $113 \pm 15$ & 88 & 136 & $4.2 \pm 1.3$ & 2.1 & 6.7 \\
\hline & SR2 & $123 \pm 23$ & 83 & 151 & $4.3 \pm 1.5$ & 2.6 & 6.4 \\
\hline & SR4 & $113 \pm 15$ & 88 & 136 & $4.2 \pm 1.3$ & 2.1 & 6.7 \\
\hline & SR7 & $126 \pm 21$ & 103 & 161 & $4.2 \pm 1.5$ & 2.2 & 6.4 \\
\hline \multicolumn{8}{|c|}{ Conference } \\
\hline \multirow[t]{4}{*}{2001} & NT & $80 \pm 15$ & 46 & 99 & $5.7 \pm 2.5$ & 2.1 & 9.0 \\
\hline & SR2 & $83 \pm 9$ & 67 & 97 & $5.6 \pm 2.5$ & 2.0 & 9.2 \\
\hline & SR4 & $79 \pm 11$ & 54 & 95 & $5.7 \pm 2.5$ & 2.1 & 9.2 \\
\hline & SR7 & $82 \pm 15$ & 46 & 110 & $5.6 \pm 2.5$ & 2.0 & 9.0 \\
\hline \multirow[t]{4}{*}{2002} & NT & $84 \pm 16$ & 55 & 120 & $3.0 \pm 1.1$ & 1.0 & 4.9 \\
\hline & SR2 & $81 \pm 19$ & 47 & 119 & $3.1 \pm 1.4$ & 0.9 & 5.9 \\
\hline & SR4 & $84 \pm 16$ & 55 & 120 & $3.0 \pm 1.1$ & 1.0 & 4.9 \\
\hline & SR7 & $83 \pm 13$ & 54 & 103 & $3.1 \pm 1.1$ & 1.5 & 5.0 \\
\hline
\end{tabular}

${ }^{\mathrm{z}} \mathrm{TT}=$ thinning treatments in which, respectively, stigmas and styles had been removed in none (control, NT), two (SR2), four (SR4), or all (SR7) the flowers in the cluster, at first bloom stage.

${ }^{\mathrm{y}} \mathrm{TCA}=$ trunk cross-sectional area $\left(\mathrm{cm}^{2}\right)$.

compatible pear cultivars of commercial interest overlap its early flowering period (Sanzol and Herrero, 2002; Sanzol et al., 2003). In this study no GA3 applications were made. The 'Conference' orchard had as a pollenizer complete rows of 'Max Red Bartlett' planted with a 4:4 ratio. At $30 \%$ full bloom, four honeybee hives per hectare were placed on each orchard.

At first bloom stage, 60 trees were selected and their sizes (i.e., trunk cross-sectional area, TCA) and flower densities (number of flower clusters per square centimeter TCA) were recorded (Table 1). Fifty flower clusters per tree with seven flowers on 2- or 3-year-old wood and situated in one uniform limb at mid-height (1.3 to $1.8 \mathrm{~m}$ aboveground) were tagged. The following style removal (SRI) treatments were applied to tagged clusters in 15 trees each: 1) styles removed in 2 flowers (SR2); 2) styles removed in 4 flowers (SR4); 3) styles removed in all flowers (SR7), and4) styles not removed in any flower (NT, control treatment). As a result, the number of flowers that were susceptible to open-pollination was 5 for SR2, 3 for SR4, and none for SR7. The stigmas and styles were always cut off in those flowers in the cluster closest to reaching anthesis. Neither additional thinning (manual or chemical) nor GA3 applications were performed. The experiment had a completely randomized design, with 4 thinning intensities and 15 replications. As the purpose of this study was to evaluate the influence of SRI under a wide range of flower densities, the latter varied greatly within each treatment (Table 1), so it was included in the design as a covariate.

Data collection. About $50 \mathrm{~d}$ after full bloom (DAFB), the fruit cluster number and the number of fruit per cluster were counted on tagged clusters for each treatment and control. This procedure was repeated at harvest and the maximum equatorial diameter of each fruit was also measured. Harvest maturity was determined by the firmness of 50 randomly chosen fruit in the orchard, taken from trees adjacent to those used for the trial. Harvest took place when the average firmness reached 5.5 to $6 \mathrm{~kg}$ for 'Blanquilla' and 6.5 to 7 for 'Conference' (Carrera, 1999). For each tree, 5 to 10 fruit were randomly taken, and fruit weight, seed number, maximum equatorial diameter, and height were measured. From the collected data, cluster set $(\%)$ at 50 DAFB and at harvest, number of fruit percluster at $50 \mathrm{DAFB}$ and at harvest, fruit shape (as length to diameter ratio), fruit weight (g), cluster weight (g), and yield per flower cluster at full bloom (YCB, g) were calculated. YCB stands for the yield per flower cluster at full bloom, i.e., the ratio of total yield obtained in tagged clusters and number of tagged clusters at full bloom.

Statistical analyses. The data were analyzed with SPSS's GLM procedure. The effect of flower density was evaluated with an analysis of covariance. The approach for determining the form of the covariate part of the model was the one suggested by Field (2000) and Litell et al. (1996), where flower density was included in the model as the covariate. First, the hypothesis that all slopes are equal was tested by including in the model terms for the main effect (SRI) and the interaction of the main effect with the covariate (flower density). When the interaction term with the covariate was not significant at the $5 \%$ level, an equal slopes model was evaluated by including in the model the covariate and the main effect. When the covariate was significant, the least square means, adjusted for the covariate, was estimated and compared with the probability of the difference adjusted with the Bonferroni correction. When the covariate was not significant, an analysis of variance was performed and the least squares means were compared with Tukey's test. Percentage values were arc-sin transformed before statistical analysis. The data for each tree were averaged before being subjected to the analysis. To determine fruit weight a regression analysis was performed for each SRI treatment between the diameter and the weight of the sampled fruit by fitting curvilinear estimation models with the Curvilinear Regression Procedure of SPSS.

\section{Results}

'Blanquilla'. The interaction between SRI and flower density was nonsignificant for any of the studied variables or years, so common slopes models were evaluated with analysis of covariance (Table 2). In both years, the covariate (flower density) was significant in all cases except for the number of fruit/cluster at harvest, seed number and fruit shape. The effects of the intensity of style removal were very similar in 2001 and 2002. At 50 DAFB (just after the second wave of fruit drop) cluster set for SR2 and SR4 treatments was similar (2001) or about $25 \%$ less (2002) than control, whereas SR7 had about $50 \%$ less cluster set. Those differences in cluster set remained at harvest. SRI treatments did not significantly affect the number of fruit per cluster either at 50 DAFB or at harvest. Seed number for SR2 and SR4 treatments was similar to that for control, whereas fruits in SR7 treatment had only misshapen seeds, smaller than fully developed ones, and contained no embryo. Fruit shape, fruit weight and cluster yield were similar for all treatments and control. YCB was significantly lower than the control only for the SR7 treatment

'Conference'. The interaction between SRI and flower density was nonsignificant for any of the studied variables or years, so common slopes models were evaluated with analysis of covariance (Table 3). Flower density was significant for most of the variables, except for seed number and fruit shape (2001 and 2002), yield per cluster (2001), number of fruit per cluster and fruit weight (2002). As with 'Blanquilla', the effects of the treatments were very similar in 2001 and 2002. At 50 DAFB, cluster set was similar for all treatments and control. However, cluster set at harvest for SR2 and SR4 was similar to that for control, whereas SR7 had about $50 \%$ less cluster set. The number of fruit per cluster either at 50 DAFB or at harvest was not significantly affected by treatments. Seed content was significantly lower than the control only for the SR7 treatment. Only the fruits for SR7 treatments were significantly more elongated than the control. Fruit weight and cluster yield were similar for all treatments and control, whereas YCB did not differ significantly from control for either treatment.

\section{Discussion}

In both years the weather was favorable for pollination and set, as day temperatures were warm $\left(13\right.$ to $\left.23^{\circ} \mathrm{C}\right)$ during the 6 weeks following 'firstbloom'stage, and nightminimawere always above $6{ }^{\circ} \mathrm{C}$. Sets and yields in 'Conference' control trees were quite similar to the expected according to the prediction model proposed by Miranda and Royo (2003) for well-pollenized pear orchards. Clustersetobtained in 'Blanquilla' control trees was about $10 \%$ to $15 \%$ lower than the expected according to the abovementioned prediction model, probably due to the lack of pollenizers. Moreover, clusters in 'Blanquilla' control trees had about $25 \%$ to $35 \%$ less yield than expected, probably because fruit had a very low number of seeds, so their sink strength was accordingly reduced (Weinbaum et al., 2001). 
Table 2. The effect of preventing the pollination in the most developed flowers in the cluster on set, fruit characteristics and yield for 'Blanquilla' pear. When the covariate, flower density (FD) was significant, values in the same column are least squared means adjusted for the covariate. When the covariate was not significant, values in the same column are least squared means.

\begin{tabular}{|c|c|c|c|c|c|c|c|c|c|c|}
\hline \multirow[b]{2}{*}{ Year } & \multirow[b]{2}{*}{ Variable } & \multicolumn{2}{|c|}{$\begin{array}{c}\text { Cluster set } \\
(\%)\end{array}$} & \multicolumn{2}{|c|}{$\begin{array}{l}\text { Fruit/cluster } \\
\text { (no.) }\end{array}$} & \multirow{2}{*}{$\begin{array}{l}\text { Seed/ } \\
\text { fruit } \\
\text { (no.) }\end{array}$} & \multirow{2}{*}{$\begin{array}{c}\mathrm{Ht} / \\
\text { diam }\end{array}$} & \multirow{2}{*}{$\begin{array}{c}\text { Fruit } \\
\text { wt } \\
(\mathrm{g})\end{array}$} & \multirow{2}{*}{$\begin{array}{l}\text { Yield/ } \\
\text { cluster } \\
\text { (g) }\end{array}$} & \multirow{2}{*}{$\begin{array}{c}\mathrm{YCB}^{\mathrm{y}} \\
(\mathrm{g})\end{array}$} \\
\hline & & $50 \mathrm{DAFB}$ & Harvest & $50 \mathrm{DAFB}$ & Harvest & & & & & \\
\hline \multicolumn{11}{|c|}{ Style removal intensity (SRI) } \\
\hline \multicolumn{11}{|c|}{2001} \\
\hline & $\mathrm{NT}^{\mathrm{y}}$ & $36 \mathrm{a}^{\mathrm{x}}$ & $29 \mathrm{a}^{\mathrm{x}}$ & 1.3 & 1.1 & $0.6 \mathrm{a}^{\mathrm{w}}$ & 1.29 & 123 & 136 & $39 a^{x}$ \\
\hline & SR2 & $37 \mathrm{a}$ & $22 \mathrm{a}$ & 1.3 & 1.1 & $0.6 \mathrm{a}$ & 1.28 & 118 & 128 & $28 \mathrm{a}$ \\
\hline & SR4 & $33 \mathrm{a}$ & $24 \mathrm{a}$ & 1.3 & 1.1 & $0.6 \mathrm{a}$ & 1.26 & 125 & 136 & $33 \mathrm{a}$ \\
\hline & SR7 & $18 \mathrm{~b}$ & $11 \mathrm{~b}$ & 1.3 & 1.1 & $0.3 \mathrm{~b}$ & 1.26 & 118 & 130 & $15 \mathrm{~b}$ \\
\hline \multicolumn{11}{|c|}{ Significance } \\
\hline & & 0.024 & 0.029 & 0.256 & 0.478 & 0.040 & 0.222 & 0.684 & 0.997 & 0.036 \\
\hline & & 0.000 & 0.008 & 0.003 & 0.099 & 0.886 & 0.983 & 0.019 & 0.015 & 0.002 \\
\hline & & 0.329 & 0.587 & 0.250 & 0.493 & 0.761 & 0.619 & 0.668 & 0.946 & 0.619 \\
\hline \multicolumn{11}{|c|}{2002} \\
\hline & NT & $63 \mathrm{a}^{\mathrm{x}}$ & $42 \mathrm{a}^{\mathrm{x}}$ & 1.5 & 1,1 & $1,8 \mathrm{a}^{\mathrm{w}}$ & 1.31 & 125 & 134 & $54 a^{x}$ \\
\hline & SR2 & $47 \mathrm{~b}$ & $33 \mathrm{~b}$ & 1.4 & 1,0 & $1,4 \mathrm{a}$ & 1.33 & 119 & 123 & $40 \mathrm{a}$ \\
\hline & SR4 & $43 \mathrm{~b}$ & $31 \mathrm{~b}$ & 1.3 & 1,1 & $1,3 \mathrm{a}$ & 1.31 & 119 & 126 & $40 \mathrm{a}$ \\
\hline & SR7 & $26 \mathrm{c}$ & $20 \mathrm{c}$ & 1.5 & 1,0 & $0,2 \mathrm{~b}$ & 1.33 & 129 & 133 & $23 \mathrm{~b}$ \\
\hline \multicolumn{11}{|c|}{ Significance } \\
\hline & & 0.001 & 0.013 & 0.158 & 0.429 & 0.001 & 0.134 & 0.252 & 0.118 & 0.004 \\
\hline & & 0.001 & 0.002 & 0.000 & 0.394 & 0.585 & 0.899 & 0.001 & 0.000 & 0.000 \\
\hline & & 0.209 & 0.473 & 0.235 & 0.779 & 0.796 & 0.305 & 0.453 & 0.206 & 0.320 \\
\hline
\end{tabular}

${ }^{\mathrm{z} Y C B}=$ yield per flower cluster at full bloom; ratio of total yield in tagged clusters and number of tagged clusters at full bloom

${ }^{y}$ Treatments in which, respectively, the stigmas and styles were cut in none (control, NT), two (SR2), four (SR4), and all (SR7) the flowers in the cluster. The stigmas and styles were always cut off in those flowers in the cluster closest to reaching anthesis.

${ }^{x}$ Least adjusted means adjusted for the covariate within columns followed by the same letter do not differ at $5 \%$ level, by Tukey's test with Bonferroni correction.

wheast adjusted means within columns followed by the same letter do not differ at 5\% level, by Tukey's test.

Table 3. The effect of preventing the pollination in the most developed flowers in the cluster on set, fruit characteristics and yield for 'Conference' pear. When the covariate, flower density (FD) was significant, values in the same column are least squared means adjusted for the covariate. When the covariate was not significant, values in the same column are least squared means.

\begin{tabular}{|c|c|c|c|c|c|c|c|c|c|c|}
\hline \multirow[b]{2}{*}{ Year } & \multirow[b]{2}{*}{ Variable } & \multicolumn{2}{|c|}{$\begin{array}{c}\text { Cluster set } \\
(\%)\end{array}$} & \multicolumn{2}{|c|}{$\begin{array}{c}\text { Fruit/cluster } \\
\text { (no.) }\end{array}$} & \multirow{2}{*}{$\begin{array}{l}\text { Seed/ } \\
\text { fruit } \\
\text { (no.) }\end{array}$} & \multirow{2}{*}{$\begin{array}{c}\mathrm{Ht} / \\
\text { diam }\end{array}$} & \multirow{2}{*}{$\begin{array}{c}\text { Fruit } \\
\text { wt } \\
(\mathrm{g})\end{array}$} & \multirow{2}{*}{$\begin{array}{c}\text { Yield/ } \\
\text { cluster } \\
(\mathrm{g})\end{array}$} & \multirow{2}{*}{$\begin{array}{c}\mathrm{YCB}^{\mathrm{y}} \\
(\mathrm{g})\end{array}$} \\
\hline & & $50 \mathrm{DAFB}$ & Harvest & $50 \mathrm{DAFB}$ & Harvest & & & & & \\
\hline \multicolumn{11}{|c|}{$\begin{array}{l}\text { Style removal intensity (SRI) } \\
2001\end{array}$} \\
\hline & $\mathrm{NT}^{\mathrm{z}}$ & 72 & $43 \mathrm{a}^{\mathrm{x}}$ & 1.7 & 1.2 & $5.4 \mathrm{a}^{\mathrm{w}}$ & $1.44 \mathrm{~b}^{\mathrm{w}}$ & 162 & 186 & $79 a^{x}$ \\
\hline & SR2 & 72 & $36 \mathrm{a}$ & 1.8 & 1.1 & $5.4 \mathrm{a}$ & $1.44 \mathrm{~b}$ & 171 & 186 & $66 \mathrm{a}$ \\
\hline & SR4 & 66 & $35 \mathrm{a}$ & 1.7 & 1.1 & $5.2 \mathrm{a}$ & $1.47 \mathrm{~b}$ & 162 & 183 & $65 a$ \\
\hline & SR7 & 68 & $18 \mathrm{~b}$ & 1.7 & 1.1 & $0.1 \mathrm{~b}$ & $1.60 \mathrm{a}$ & 163 & 175 & $32 \mathrm{~b}$ \\
\hline \multicolumn{11}{|c|}{ Significance } \\
\hline & & 0.408 & 0.000 & 0.280 & 0.191 & 0.001 & 0.004 & 0.927 & 0.426 & 0.000 \\
\hline & & 0.000 & 0.000 & 0.001 & 0.000 & 0.997 & 0.068 & 0.007 & 0.736 & 0.000 \\
\hline & & 0.591 & 0.130 & 0.173 & 0.101 & 0.286 & 0.524 & 0.993 & 0.616 & 0.644 \\
\hline \multicolumn{11}{|c|}{2002} \\
\hline & NT & 69 & $57 a^{x}$ & 1,6 & 1.2 & $7.5 \mathrm{a}^{\mathrm{w}}$ & $1.51 \mathrm{~b}^{\mathrm{w}}$ & 172 & 200 & $114 a^{x}$ \\
\hline & SR2 & 69 & $52 \mathrm{a}$ & 1,5 & 1.1 & $6.5 \mathrm{a}$ & $1.43 \mathrm{c}$ & 184 & 207 & $110 \mathrm{a}$ \\
\hline & SR4 & 72 & $52 \mathrm{a}$ & 1,6 & 1.2 & $6.4 \mathrm{a}$ & $1.52 \mathrm{~b}$ & 170 & 208 & $109 a$ \\
\hline & SR7 & 72 & $36 \mathrm{~b}$ & 1,8 & 1.2 & $0.4 \mathrm{~b}$ & $1.62 \mathrm{a}$ & 174 & 206 & $74 \mathrm{~b}$ \\
\hline \multicolumn{11}{|c|}{ Significance } \\
\hline & & 0.155 & 0.022 & 0,695 & 0.476 & 0.003 & 0.001 & 0.077 & 0.494 & 0.029 \\
\hline & & 0.002 & 0.000 & 0,384 & 0.000 & 0.426 & 0.883 & 0.176 & 0.002 & 0.000 \\
\hline & & 0.478 & 0.250 & 0,856 & 0.912 & 0.201 & 0.105 & 0.100 & $0 ., 027$ & 0.197 \\
\hline
\end{tabular}

${ }^{\mathrm{z} Y C B}=$ yield per flower cluster at full bloom; ratio of total yield in tagged clusters and number of tagged clusters at full bloom

y Treatments in which, respectively, the stigmas and styles were cut in none (control, NT), two (SR2), four (SR4), and all (SR7) the flowers in the cluster. The stigmas and styles were always cut off in those flowers in the cluster closest to reaching anthesis.

'Least adjusted means adjusted for the covariate within columns followed by the same letter do not differ at $5 \%$ level, by Tukey's test with Bonferroni correction.

wLeast adjusted means within columns followed by the same letter do not differ at $5 \%$ level, by Tukey's test.

Results from different cultivars and years differed slightly, but overall responses were fairly consistent. In all experiments flower density was generally significant in cluster set, fruit/cluster number, and cluster yield, so that there was a negative influence of flower density on cluster set and yield. These results imply greater competition for resources between developing fruit as the flower density increases, right from the first stages of development, as commonly known and widely reported in previous research(Dennis, 1986; Knight, 1980; Miranda and Royo, 2003; Stover, 2000).

Results obtained for SR2 and SR4 suggest that clusters in which all flowers are undamaged have a similar ability to set as those in which the pollination has been thwarted in two or four flowers (SR2 and SR4 treatments, respectively). These results agree with previous research available for apple (Ferree et al., 2001; Goffinet et al., 1996; Miranda et al., 2005) in which well developed lateral flowers had a similar setting ability as the most developed flower or whole clusters. Seed number at harvest and fruit shape in this study were not affected in SR2 and SR4 treatments. This result indicates that those clusters had a similar ability to be pollinated and form viable seeds as undamaged clusters under natural autogamy ('Blanquilla' treatments) as well as under crosspollination ('Conference' treatments). Ferree et al. (2001) and Miranda et al. (2005) found similar results for some apple cultivars. This 
result reinforces the argument that behavior for partially damaged clusters is similar to that of whole clusters.

The SR 7 treatments yielded less fruit in both cultivars, and displayed the typical features of parthenocarpy: the fruit were seedless or the flat empty seeds did not contain germ but some rudimentary endosperm, along with a more elongated shape (in 'Conference'). Fruit shape in 'Blanquilla' was the expected for this cultivar for all treatments and control, in spite of the low seed content, though about $10 \%$ of misshapen pears (visually evaluated) were obtained in all treatments. Similar results were found by Sharifani and Jackson (2001) in a pollination study with 'Packham's Triumph'. 'Blanquilla' is a cultivar with low parthenocarpic strength and erratic self-fertility (Sanzol, 2001; Sanzol et al., 2003). However, spring weather had favored a certain self-fertile set with single-seeded fruit, especially in 2001 treatments. This weak set and seed content had allowed that partenocarpic fruit, though less competitive, remained until harvest in all treatments and control. In the highly parthenocarpic 'Conference' (Nyeki et al., 1998, 2000), unseeded fruit only appeared in SR7 treatments, because the presence of highly seeded fruit in open pollinated clusters reduced the ability of the unpollinated flowers to set (Goldwin, 1984).

Fruit weight and cluster yield were similar for all 'Blanquilla' treatments in both years, and similar results were found for 'Conference'. Fruit weight depends on crop load, fruit number per cluster and seed content (Miranda and Royo, 2003; Stover, 2000; Weinbaum et al., 2001). Competition among fruit can be due to fruit number on the same spur (intra-spur competition), or due to the number of fruit clusters per tree (inter-spur competition); seed content also enhances the fruit's competitive ability so that parthenocarpic (unseeded) fruit are more prone to drop than seeded ones (Goldwin, 1984; Strang et al., 1980). The clusters in the SR7 treatment were less subjected to inter-spur competition, even at early stages of development, so their fruit could match the size of the control.

Yield perflower cluster at full bloom (YCB) was similar for SR2 and SR4 treatments and control both years as a consequence of similar fruit size and fruit per cluster number. However, clusters from SR7 treatments yielded less than the rest of the treatments, due to lower cluster set. Therefore, the reduced set of parthenocarpic clusters implies yield reductions ranging between $40 \%$ and $60 \%$ in 'Conference', and up to about $60 \%$ in 'Blanquilla'. These losses found in 'Blanquilla' for SR7 treatments could be higher in well cross-pollenized orchards. According to the yield estimation method proposed by Miranda and Royo (2003), the estimated YCB for 'Blanquilla' control trees, under well-pollenized conditions, should have ranged between about $50 \mathrm{~g} \mathrm{(2001)}$ and about $85 \mathrm{~g}$ (2002), so the expected yield reduction would rise up to $70 \%$ to $80 \%$. Our study was undertaken on well developed spurs from 2- to 3-year-old wood. Similar treatments carried out on lower quality spurs, such as older apical spurs or axillary clusters (Webster,
2002) probably had had lower fruit set and fruit weight.

In conclusion, flower position in the cluster had little influence on shape, size, or seed content, and the growth potential of fruit from partially damaged clusters in their most developed flowers seems to be similar to that of undamaged clusters, as previously found in apple (Ferree et al., 2000, 2001; Goffinet et al., 1996; Miranda et al., 2005). Our results show that two generally taken for granted assumptions, i.e., 1) thinning has to be preferentially selective, so that the first flowers in the cluster have to be kept and 2) the loss of the most developed flowers in the cluster leads to lower yields, seem to have no sound basis, at least when thinning is performed at bloom stages. Therefore, a nonselective mode of action for a blossom thinner (chemical or mechanical) should not be considered as disadvantageous, and that after spring frosts of moderate intensity which only damage the most developed flowers in the clusters, expectable yield losses should be minimal.

\section{Literature Cited}

Baldini, E. 1992. Arboricultura general. Mundi Prensa, Madrid, Spain.

Black, B.L., M.J. Bukovac, and M. Stopar. 2000. Intraspur fruit competition and position influence fruit size at harvest and response to chemical thinning agents in spur-type 'Delicious' apple. Acta Hort. 527:119-125.

Bound, S.A. and K.M. Jones. 1997. Investigating the efficacy of endothal as a chemical thinner of red 'Delicious' apple. J. Hort. Sci. 72: 171-177.

Byers, R.E. and C.G. Lyons, Jr. 1985. Peach flower thinning and possible sites of action of desiccating chemicals. J. Amer. Soc. Hort. Sci. 110:662-667.

Cambra, M. and J. Herrero. 1978. Estudios sobre la irregularidad de producción de la variedad de peral "Agua de Aranjuez". An Aula Dei 14:76-94.

Carrera, M. 1999. Variedades y calidad de las peras en Aragón. Asociación Profesional de Empresas de Productos Hortofruticolas de la Provincia de Zaragoza, Calatayud, Spain.

Dennis Jr, F. G. 1986. Apple, p. 1-41. In: S.P. Monselise (ed.). CRC handbook of fruit set and development. 1st ed. CRC Press, Boca Raton, Fla.

Dennis Jr, F.G. 2003. Flowering, pollination and fruit set and development, p. 153-166. In: D.C Ferree and I.J. Warrington (eds.). Apples. Botany, production and uses CABI Publ., Wallingford, U.K.

Dennis Jr, F.G. 2000. The history of fruit thinning. Plant Growth Regulat. 31:1-16.

Dibuz, E. 1997. Types of blooming sequence of flowers in the inflorescence of pear varieties. Acta Hort. 475:231-235.

Fallahi, E. and K.M. Willemsen. 2002. Blossom thinning of pome and stone fruit. HortScience $37: 474-477$.

Ferree, D.C., B.L. Bishop, J.R. Schupp, D.S. Tustin, and W.M. Cashmore. 2001. Influence of flower type, position in the cluster and spur characteristics on fruit set and growth of apple cultivars. J. Hort. Sci. Biotechnol. 76:1-8.

Ferree, D.C., J.R. Schupp, D.S. Tustin, and W.M. Cashmore. 2000. Does 'king dominance' differ among apple cultivars and sites? Acta Hort. 527:27-34.
Field,A.P. 2000. Discovering statistics using spss for windows: advanced techniques for the beginner. Sage, London, U.K.

Goffinet, M.C.,A.N.Lakso, and T.L. Robinson. 1996. Fruit drop in 'Empire' apple by position within the cluster in unthinned trees vs. trees thinned to single fruited clusters. HortScience 31:665.

Goldwin, G.K. 1984. Factors affecting hormoneassisted setting on cox's apple. Acta Hort. 149:161-171

Knight, J.N. 1980. Fruit thinning of the apple cultivar Cox's Orange Pippin. J. Hort. Sci. 114:852-855

Littell, R.C., G.A. Milliken, W. Stroup, and R.D. Wolfinger. 1996. SAS System for mixed models. SAS Inst., Cary, N.C.

Masseron,A. 2002. Pommier, le mur fruitier. Éditions Centre Technique interprofessionnel des fruits et légumes, Paris, France.

Miranda, C. and J.B. Royo. 2003. Statistical model estimates potential yields in pear cultivars 'Blanquilla' and 'Conference' before bloom. J. Amer. Soc. Hort. Sci. 128:452-457.

Miranda, C., L.G. Santesteban, and J.B. Royo. 2005. Removal of the most developed flowers influences fruit set, quality, and yield of apple clusters. HortScience 40:353-356.

Nyeki, J., M. Göndörne, and M. Szabo. 1994. Recent data on fertilization of pear varieties. Acta Hort. 367:87-96.

Nyeki, J., M. Soltèsz, and J. Iváncsics. 1998. Natural tendency to parthenocarpy of pear varieties in Hungary. Acta Hort. 475:367-377.

Nyeki, J., M. Soltèsz, and J. Iváncsics. 2000. Selffertility of pear varieties conditioned by natural self-pollynation (autogamy). Intl. J. Hort. Sci. 6:110-113

Prognosfruit. 2004. Apple and pear crop forecasts 2004. European Union and other countries. Eurofel-Databank, Lublin, Poland.

Sanzol, J. 2001. Mecanismos reproductivos que regulan la fructificación en peral (Pyrus communis L.) cv. 'Agua de Aranjuez'. PhD diss. Public. Univ. Nav.

Sanzol, J. and M. Herrero. 2002. Fructificación del cultivar de peral Agua de Aranjuez. Necesidades de polinización. Fruticultura Prof. 130:25-32.

Sanzol, J., P. Rallo, and M. Herrero. 2003. Stigmatic receptivity limits the effective pollination period in 'Agua de Aranjuez' Pear. J. Amer. Soc. Hort. Sci. 128:458-462.

Sharifani, M.M. and J.F. Jackson. 2001. Influence of caging on pollination and fruit set of two pear cultivars. Acta Hort. 561:235-241.

Stover, E. 2000. Relationship of flowering intensity and cropping in fruit species. HortTechnology 10:729-732.

Strang, J.G., P.B. Lombard, and M.N. Westwood. 1980. Effect of simulated frost injury on fruit development in three pear cultivars. J. Amer. Soc. Hort. Sci. 105:63-65.

Webster, A.D. 2002. Factors influencing the flowering, fruit set and fruit growth of european pears. Acta Hort. 596:699-709.

Weinbaum, S.A., T.M. DeJong, and J. Maki. 2001. Reassessment of seed influence on return bloom and fruit growth in 'Bartlett' pear. HortScience 36:295-297.

Wertheim, S.J. 2000. Developments in the chemical thinning of apple and pear. Plant Growth Regulat. 31:85-100.

Westwood, M.N. 1993. Temperate zone pomology. Timber Press, Portland, Ore.

Westwood, M.N.,L.L.P. Batjer, and H.D. Billingsley. 1967. Cell size, cell number and fruit density of apples as related to fruit size, position in the cluster and thinning method. Proc. Amer. Soc. Hort. Sci. 91:51-62. 